\title{
Review
}

Neonatology

\section{Ignored Papers, Invented Quotations: A History of Fetal Alcohol Syndrome}

\author{
Michael Obladen \\ Department of Neonatology, Charité University Medicine, Berlin, Germany
}

\section{Keywords \\ Embryopathy - Fetopathy · Fetal alcohol syndrome $\cdot$ Fetal alcohol spectrum disorders · Teratology $\cdot$ Eugenics $\cdot$ History}

\begin{abstract}
Given the high rate of alcoholism throughout history, its effects on the fetus may have existed for millennia. But, the claim that Greeks and Romans were aware of fetal alcohol syndrome rests on incorrect citations. From 1725, maternal alcohol consumption was associated with retarded fetal growth and neurological anomalies. From 1809, scientists followed Lamarck's theory that the disorders parents acquire during their lifetime are passed on to their offspring. Fetal effects were thought to be inherited mainly from the father. During the 19th century, parental alcoholism became associated with malformations. In 1915, Ballantyne distinguished genetic influence via germ cells from toxin's effect on the embryo. Fetal alcohol syndrome was characterized by Rouquette [Influence de la toxicomanie alcoolique parentale sur le développement physique et psychique des jeunes enfants] in 1957 and Lemoine etal. [Ouest Medical. 1968;21:476482] in 1968 as consisting of 4 features: (A) facial anomalies (narrow forehead, retracted upper lip, and cupped ears), (B) severe growth retardation (prenatal and postnatal), (C) malformations (limbs, cardiac, and visceral), and (D) central nervous system anomalies (hyperexcitability and mental retardation). But, their studies, written in French, remained disregarded. In 1973, Jones et al. [Lancet. 1973;302:999-1001] reported "the first association between maternal alcoholism and aberrant morphogenesis in the offspring." The history of
\end{abstract}

Karger fetal alcohol syndrome reveals shortcomings in citation practice. Alleged quotations remained unverified, non-English publications neglected, and short quotations taken out of context. Prejudiced by religious and abstinence groups, reports on alcohol damage to the unborn were fraught with emotions, moralizing, social implications, and presentism, the interpretation of past events with present knowledge.

(c) 2021 S. Karger AG, Basel

\section{Introduction}

Fermented beverages have accompanied mankind since the Neolithic age. Using gas chromatography-mass spectrometry, McGovern et al. [1] found a fermented mixture of rice, honey, and fruit in pottery jars from the 7th millennium BCE in the Henan province of China. Beverages with $>5 \%$ alcohol were consumed throughout human history, and distilled spirits with $>20 \%$ alcohol were known to Egyptians and Babylonians around 2,000 BCE $[2,3]$. Aztecs consumed pulque, the fermented juice of the agave plant. Fetal alcohol syndrome was described by Lemoine et al. [4] in 1968. In addition to the full-blown syndrome, fetal alcohol "spectrum disorders" include partial fetal alcohol syndrome and alcohol-related neurodevelopmental disorders, which are not part of this article. Fetal alcohol syndrome is a leading cause of mental retardation. Its historic sources were critically analyzed by Abel [5, 6] and James Sanders [7] and the more recent history by Jones and Streissguth [8] and Lemoine $[9,10]$. This study aims to explain why prenatal alcohol damage

Correspondence to:

Michael Obladen, michael.obladen@charite.de 
was understood so late and why so many publications contain contradictions. In this study, alcohol always means ethanol.

\section{Reports from Antiquity}

Given today's prevalence of $0.5 \%$ in developed countries $[11,12]$, fetal alcohol syndrome may have existed for millennia. Many authors could not refrain from "proving" this hypothesis with historic citations [13-18]. Even Biblical sources have been cited to prove that Hebrews acknowledged the danger for the fetus $[13,14]$. Judges 13:3-4 is usually quoted because an angel advised Samson's mother "thou shalt conceive, and bear a son. Now therefore beware, I pray thee, and drink not wine nor strong drink." As Abel pointed out [5], the advice did not refer to every pregnant woman, as the text continued "for the child shall be a Nazarite (consecrated to the Lord) unto God from the womb." Abel also demonstrated [6] that the claim that fetal alcohol syndrome was known to Greeks and Romans was borrowed from Robert Burton's "Anatomy of Melancholy" of 1621. Under the pseudonym "Democritus Junior," the Anglican priest published an encyclopedic monograph which sold well, went through 8 editions up to 1676 , and was still being reprinted in the 19th century [19]. Although his "citations" sound convincing, they were often incorrect, taken out of context, or simply fabricated. A few examples are as follows.

(1) Burton claimed the Roman author Gellius [20] had written, "if a drunken man get a child, it will never likely have a good braine," while Gellius criticized wet nurses as "dishonest, unchaste, or drunken." (2) Burton quoted the Greek author Plutarch [21] as having written "one drunkard begets another," but in fact he had stated "that love was like drunkenness." (3) Burton claimed that Aristotle (322 BCE) wrote [22] "foolish, drunken or haire-braine women, for the most part bring forth children like unto themselves, morosos and languidos," but this citation cannot be verified either.

The 17 th century quotations are frequently incorrect, especially when clerics were trying to support their moral claims. What is remarkable, however, is that Burton's "quotations" have persisted in the medical literature for 400 years. Undoubtedly, Greeks and Romans believed that at the time of conception, both mother and father should be sober, as Plato (427-347 BCE) emphasized in "The laws" [23]: [674 b]: "judges while on duty, should taste no wine at all nor should anyone do so by night - be he man or woman - when proposing to procreate children." [775c-d]: "Drinking to excess is a practice that is nowhere seemly and certainly it is not so for those who take marriage seriously that the child that is begotten may be sprung from the loins of sober parents; moreover, it is not right that procreation should be the work of bodies dissolved by excess of wine, but rather that the embryo should be compacted firmly, steadily, and quietly in the womb; when drunk, a man is clumsy and bad at sowing seed, and is thus likely to beget unstable and untrusty offspring, crooked in form and character."

The Romans did not claim that alcohol itself was toxic for the fetus. They held maternal imagination responsible, as did Soranus around 200 CE [24]: "In order that the offspring may not be rendered misshapen, women must be sober during coitus because in drunkenness the soul becomes the victim of strange phantasies."

\section{6th and 17th Centuries: "Very Wholesome"}

Renaissance authors did not consider alcohol unwholesome during pregnancy. Roesslin [25] ordered in 1513: "And for drink, let her use good ripe wine mixed with water." Fernel [26] was aware of fetal addiction in 1554: "Maternal blood, the fetuses' first aliment, influences his temperament and constitution. He will need what she is used to. Thus an alcoholic mother will bring forth an alcoholic fetus, a mother habituated to drugs, a drug-addict." French pioneers of obstetrics treated vomiting and the morning sickness of pregnant women with wine. In 1620, Guillemeau [27] recommended drinking "wine diluted with water," and Mauriceau [28] specified in 1668: "She should drink old wine, better red than white, which is warmed and diluted with fresh fountain water." The Nurse's Guide of 1729 encouraged mothers and wet nurses to drink beer or ale [29]: "The drinking of MaltDrink (cervisia) produces a great deal of milk, and is very wholesome."

\section{8th Century: "Pigmy Size"}

At the beginning of the 18th century, the British parliament lowered taxes and encouraged the sale of strong spirits. Gin consumption rose to epidemic proportions [30]. In January 1725, the Royal College of Physicians petitioned [31] to the House of Commons against the pernicious and growing use of spirits, which rendered "great 


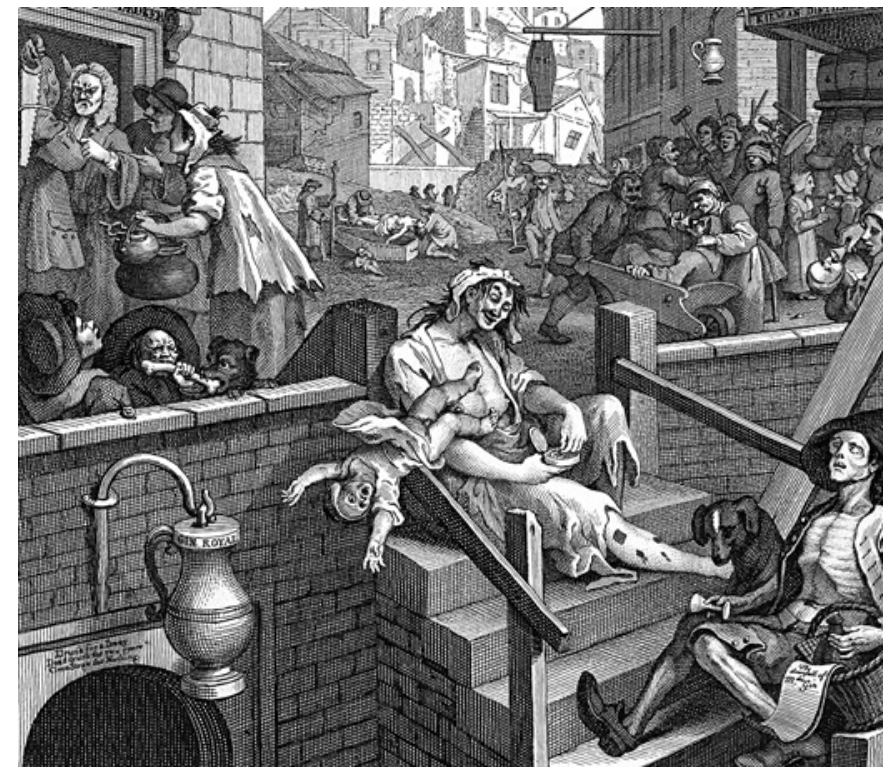

Fig. 1. "Gin Lane" (detail), copper engraving by William Hogarth, 1751 [71]. Hogarth was a lifelong benefactor and governor of the London Foundling Hospital since 1741. The illustration depicted the evils of drinking gin and aimed to support the British legislation "Gin Act," passed in 1751.

numbers of both sexes diseas'd, not fit for business, poor, a burthen to themselves, and too often the cause of weak, feeble, and distemper'd children." In the same year, the Middlesex Justices of Peace reported [32]: "Unhappy Mothers habituate themselves to these Distilled Liquors, whose Children are born weakly and sickly, and often look shrivel'd and old, as though they had number'd many Years."

Alcoholism among the poor was drastically depicted by William Hogarth in 1751 (Fig. 1). The "Mother Gin Controversy" led to legislation that slowly reduced the consumption of distilled liquors [33]. In 1751, the Anglican priest Stephen Hales repeated the Justices' claim [34]: "Nay, the unhappy influence of these liquors reaches even to the children that are yet unborn. Of this we have too frequent instances, where the unhappy mothers habituate themselves to these distilled liquors, whose children, when first born, are often either of a diminutive, pigmy size, or look withered and old, as if they had numbered many years, when they have not, as yet, alas! attained to the evening of the first day." Morris [35] evaluated the tables of christenings and burials within London from 1601 to 1750 . He linked the drinking of spirituous liquors to "sterility of the females and renders such as are born meagre and sickly, and unable to pass through the first stages of life."

History of Fetal Alcohol Syndrome

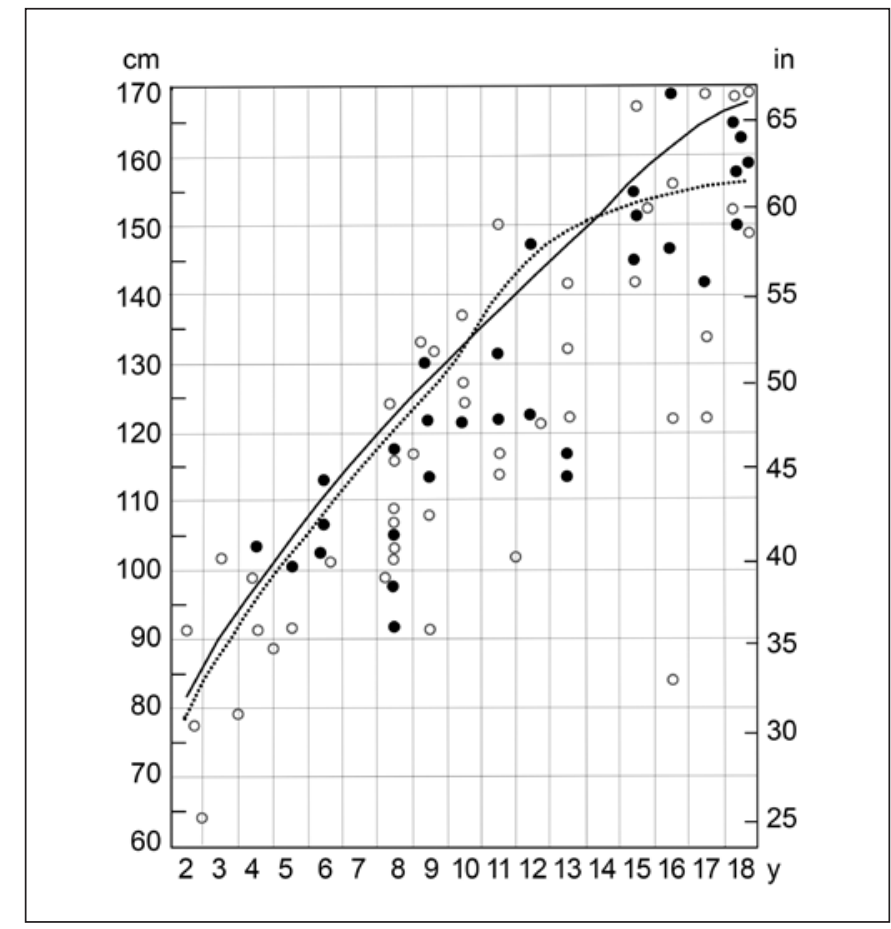

Fig. 2. Body length of 76 Massachusetts children classified as "idiots," the progenitors of whom were ascertained as alcoholics (closed circles) or nonalcoholics (open circles). Data from Howe [39], 1848. Comparison with normal Boston school children, 1877: straight line, boys; dotted line, girls [72].

\section{9th Century: “Hereditary Alcoholism”}

The temperance movement originated in the 1820 s in many countries, led by churches and dominated by males. But, physicians played down alcohol dangers for women, as did Bouchut in his "Mothers Guide" [36]: "The nurses may drink wine in small quantity (one bottle a day, with water), beer, and cider, as they are used to." From 1809, most scientists acknowledged Lamarck's theory that physical characteristics and diseases that parents acquired during their lifetime are passed on to their offspring, as did Glasgow physician MacNish [37] in 1828: "From the general defect of vital power in the system, the children of drunkards are neither numerous nor healthy. They are usually puny and emaciated, and more than ordinarily liable to inherit all the diseases of their parents. Their intellect is also, in most cases, below the general standard."

The Select Committee of the British House of Commons queried in 1834 [38]: "Is there any difference in the appearance of such children?" The physician Robert Dods answered: "Sometimes not appreciable, at others quite distinct; the infant has frequently not merely a want

Neonatology 2021;118:647-653 
of healthy aspect, of plump, round outline, but a starved, shrivelled, and imperfect look."

Mandated by the legislature, Howe [39] studied the "condition of 574 human beings considered as idiots" in Massachusetts, half of them in almshouses. From 1846 to 1850 , he wrote several reports to the government, with a wealth of information in extensive tables: "Of the 359 idiots, the condition of whose progenitors was ascertained, 99 were the children of drunkards; the children of such persons are feeble in body and weak in mind." The author did not discern maternal from paternal inebriety, nor prenatal from postnatal growth retardation. He understood the association of parental alcoholism, short stature, microcephaly, and idiocy (Fig. 2, 3), but his explanation conformed to the eugenic doctrine of the time.

In 1874 in the Paris Salpetrière Hospital, Hippolyte Martin recorded the family histories of 83 epileptic patients born to alcoholic parents [40]: 169 of the 327 offspring died in early childhood and a third of the survivors suffered seizures. Haddon [41] of Manchester wrote in 1876: "Children (of intemperate women) born at the full time are generally weak and puny, and likely to fall at an early age victims to disease;... it is possible that a large proportion of our excessive infant mortality may be due to the malnutrition of the embryo, caused by the use of alcohol." In Liverpool, Sullivan [42] analyzed the reproductive history of the women's prison inmates in 1899: "Drunken mothers (21 cases) had 125 children, of whom $55 \%$ died under 2 years. Sober mothers (28 cases) had 138 children, of whom $24 \%$ died under 2 years."

\section{0th Century: "Teratogen"}

In 1899, Nicloux [43] found that alcohol passed readily through the human placenta yielding a fetal blood concentration almost equal to that in maternal blood. In 1915, Ballantyne [44] of Edinburgh, founder of antenatal medicine and the journal Teratologia, clearly distinguished the genetic influence via germ cells from a toxin's influence on the embryo: "The hereditary aspects of the subject neglect the more immediately practical ones when the child of a mother who is given to alcoholism is living within her womb." Two years later Ballantyne [45] added: "It may in the future be shown that alcohol has the power of picking out certain tissues, or even organs, in the fetus and embryo, and of attacking certain constituents of the germ cell and there may come a necessity to give to these particular changes a specific and defining term."

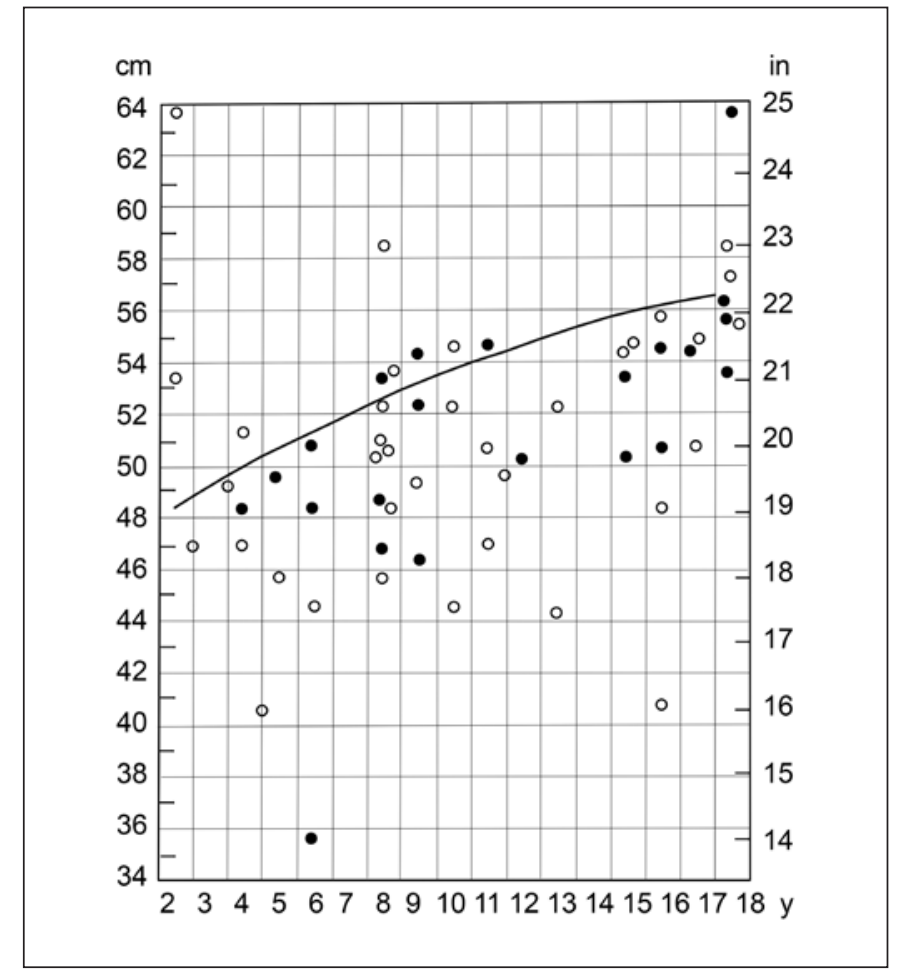

Fig. 3. Head circumference of 58 Massachusetts children classified as "idiots," the progenitors of whom were ascertained as alcoholics (closed circles) or nonalcoholics (open circles). Data from Howe [39] 1848. Straight line: median head circumference of normal Washington school children, 1897 [73].

But, political developments did not look favorably on teratology. World War I interrupted basic research in Europe, and prohibition laws of 1919 reduced drinking as a significant social problem in the USA. Nazi Germany made eugenics a state doctrine and declared alcoholism a flawed character trait rather than a disease. The "Law for the Prevention of Hereditarily Diseased Offspring," passed in 1933 [46], forced the "eugenic" sterilization of alcoholics. World War II halted high-quality research. By 1967, alcohol teratogenicity was forgotten or ignored to such an extent that intravenous ethanol was introduced to suppress premature labor [47], a treatment that persisted in the USA until 1978 [48].

At the Bicêtre hospice in 1952, Desclaux and coworkers [49] studied electroencephalograms of mentally retarded children aged 7-18 years. They found altered traces (delta rhythm) in children of alcoholic parents, but not in other forms of retardation or in normal controls. At the Paul Parquet nursery in Neuilly (near Paris), Jacqueline Rouquette [50] studied 100 children of alcoholic parents in $1957[10,50]$. She discerned alcoholism of the father $(n$ 
$=42)$, the mother $(n=28)$, and both parents $(n=30)$ and detected birth weights below 2,500 g, severe mental retardation, and stunted postnatal growth particularly in infants born to alcoholic mothers. In addition, Rouquette [50] described "the alcoholic infant's portrait the head is often small the nose is turned up, its root flat the upper lip is short and retracted, a frontal angioma persists during the first months the infant is irritable, its movements jerky and awkward (postnatal) growth is severely retarded." Among her 100 "alcoholic infants," remarkably many had congenital malformations: harelip $(n=3)$, other face malformations $(n=2)$, hydrocephalus $(n=3)$, and cardiac malformations $(n=4)$. In Nantes, $400-\mathrm{km}$ distant, Paul Lemoine [51] saw alcohol embryo-fetopathies at the University Hospital and suspected ethanol as a teratogen for the human embryo. He reported 15 cases to the Medical-Surgical Society in March 1964 and more completely to the Pediatric Society in April $1967[10,51]$ and published a study on 127 cases in 1968 [4]. To Lemoine's 61 cases, added 66 others examined by Borteyru [52] in the social health dispensaries. Lemoine characterized the syndrome to consist of 4 features: (A) facial anomalies (narrow forehead, retracted upper lip, and cupped ears), (B) severe growth retardation (prenatal and postnatal), (C) malformations (limbs, cardiac, and visceral), and (D) central nervous system anomalies (hyperexcitability and mental retardation). His explanation focused on chronic maternal alcoholism: "Being immersed for nine months in an alcoholic bath easily explained the anomalies seen in the children." But his study, written in French and originating far from Paris, remained disregarded.

At the King County (Harborview) Hospital in Seattle, pediatric resident Christy Ulleland and colleagues [53] observed 12 babies from 1968 to 1969 and reported on them in May 1970 at the American Pediatric Society in Atlantic City, NJ, USA: "Infants of alcoholic mothers are at high risk for pre- and postnatal growth and developmental failure," and in 1972 [54]. In February 1973, Ulleland's children were shown to David Smith, professor of pediatrics and specialist in dysmorphology, and his postdoctoral fellow Kenneth Jones [8]. On June 9, 1973, Jones published (with Smith and Ulleland as co-authors [53]) "Pattern of Malformation in Offspring of Chronic Alcoholic Mothers" in the Lancet [55], claiming "this seems to be the first reported association between maternal alcoholism and aberrant morphogenesis in the offspring." Within a few years, alcohol embryofetopathy was confirmed in large cohorts in Germany [56], the USA [57], Britain [58], and many other countries.

History of Fetal Alcohol Syndrome

\section{Misrepresentation and Sloppy Quotation}

Jones [8] remembered in 2010: "Soon after the initial publications describing fetal alcohol syndrome, a study of Dr. Paul Lemoine of Nantes, France, was identified. One of us (K.L.J.) wrote to Dr. Lemoine, and he wrote back saying that he had published a study in 1968 in which he identified features very similar to what we had described in Lancet." Lemoine [10] remembered the sequence of events differently: "Smith in Seattle, after reading the abstract on my work in the Archives, published 8 cases with the same conclusions. He wrote me asking for my complete text. This is an amusing fact: the 127 cases of a modest pediatrician from Brittany did not create any interest, whereas 8 American cases became immediately convincing ... in the whole world."

Reviewing historical misrepresentations in science in 1998 [59], Shibley [59] found that the studies of Jones et al. $[13,55]$ had been cited a combined total of 1,736 times, while that of Lemoine et al. [4] had been cited only 156 times since its publication. This is not the forum to define which research deserves citation in historic contexts. But, the history of fetal alcohol syndrome does shed light on shortcomings of citation practice in medicine. Incorrect quotations were carelessly adopted and led to persisting erroneous assumptions. Non-English publications were neglected. Short quotations were taken out of context. The sequence of publications was inverted by Warner and Rosett [14]: "A neglected report by Lemoine et al. [4] concerning 127 offspring of alcoholic parents is the most striking confirmation of the observation of Jones et al. $[13,55]$." Sloppy citations obviously did not ruin academic reputation in the 1970s.

\section{Pathogenetic Mechanism}

From 1880, researchers tried to provoke embryonic malformations with ethanol in animal fetuses, as did Frédéric Combemale [60] at the Montpellier insane asylum in 1888, who intoxicated dogs; Charles Stockard at Cornell University from 1912, who treated guinea pigs [61]; and Raymond Pearl [62] at the Maine Agricultural Experiment Station, who inebriated chickens from 1913. Not knowing that embryotoxins are highly species specific, and chained to the doctrine of their time, their research focused on paternal effects. When indeed abnormal offspring were born, damage to the germ cells seemed proven, and the chance to understand the teratogen was missed.

Neonatology 2021;118:647-653

DOI: $10.1159 / 000518534$ 
Human fetal alcohol dehydrogenase has only 3-4\% of adult activity per gram of liver tissue [63]. In 1971, Seppälä et al. [64] found that the newborn takes twice as long as the mother to eliminate alcohol. Errors in migration led to diminished brain growth and structural anomalies [65]. Molecular mechanisms remained unclear. In the developing brain, alcohol impairs gene expression of the guidance cue and receptor families required for axon growth [66].

\section{Epidemiology}

Population-based studies established a worldwide prevalence of about $0.5 \%$ for fetal alcohol syndrome [11], ranging from a minimum of $0.1 \%$ in Australia to a maximum of 4.5\% in South Africa [67]. Among 116 children in an isolated native Indian community in British Columbia, Robinson et al. [68] identified 14 children with the fullblown syndrome and another 8 with a partial syndrome. The frequency of "alcohol spectrum disorders" is 2-8 times higher and even more variable due to different definitions, measurements, and age of the study populations. In Europe, the per capita consumption is up to $10 \mathrm{~L}$ of pure alcohol per year, which translates to $22 \mathrm{~g}$ per person per day [69]. Together with the fact that $>40 \%$ of pregnancies are unintended [70], a huge public health problem emerged.

\section{Conclusions}

Given the high rate of alcoholism throughout history, fetal alcohol syndrome may have existed for millennia. Reliable reports, however, are available only from 1725 about retarded growth and neurological abnormalities. Why was the obvious, clear pattern detected so late? Infants with low birth weight frequently died soon after birth, and those with cardiac malformation died before mental retardation became manifest. Fetal growth retar- dation was confused with prematurity or lumped together as "weaklings," "puny," or "shriveled." Martin [16] hypothesized that maternal drinking could account for significant proportions of infant mortality in former centuries. Up to 1866 , diseases characterized by mental retardation (Down's, hypothyreosis, and postasphyxia) were not discerned. Assuming maternal alcoholism to be rare, fetal effects were interpreted as hereditary, resulting mainly from the father, and acting by degenerated germ cells. Why do so many articles on fetal alcohol syndrome contain false citations? Ballantyne [45] gave us an answer a century ago: "It would be preferable could the subject (alcohol and antenatal child welfare) be discussed in the cold, clear air of pure science, far removed from emotionalism and unhampered by ethical limitations and religious exhortations." Prejudiced by religious and abstinence groups, reports on alcohol damage to the unborn are fraught with emotions, moralizing, psychology, and social implications. To these add the intrinsic problems of retrospective diagnosis and presentism, the interpretation of past events with present knowledge.

\section{Acknowledgments}

The author would like to thank Mme. Jeanne Legardinier, Bibliothèque de l'Académie Nationale de Médecine, Paris, for providing a copy of Rouquette's dissertation, Sieghard Irrgang, Kassel, for help with the translations from Latin, and Carole Cürten, University of Freiburg, for editing the English language.

\section{Conflict of Interest Statement}

The author has no conflicts of interest to declare.

\section{Funding Sources}

The author received no funding for this work.

\section{References}

1 McGovern PE, Zhang J, Tang J, Zhang Z, Hall GR, Moreau RA, et al. Fermented beverages of pre- and proto-historic China. Proc Natl Acad Sci USA. 2004;101:175938.

2 Fairley T. Notes on the history of distilled spirits, especially whisky and brandy. Analyst. 1905;30(354):293-306.

3 Levey M. Chemistry and chemical technology in ancient Mesopotamia. Amsterdam, New York: Elsevier; 1959.
4 Lemoine P, Harousseau H, Borteyru JP, Menuet JC. Les enfants de parents alcooliques. Anomalies observées à propos de 127 cas. Ouest Medical. 1968;21:476-82.

5 Abel EL. Was the fetal alcohol syndrome recognized in the ancient Near East? Alcohol Alcohol. 1997;32:3-7.

6 Abel EL. Was the fetal alcohol syndrome recognized by the Greeks and Romans? Alcohol Alcohol. 1999;34:868-72.
7 Sanders JL. Were our forebears aware of prenatal alcohol exposure and its effects? A review of the history of fetal alcohol spectrum disorder. Can J Clin Pharmacol. 2009;16:e288-95.

8 Jones KL, Streissguth AP. Fetal alcohol syndrome and fetal alcohol spectrum disorders: a brief history. Int J Law Psychiatry. 2010;38(4): 373-82.

9 Lowenfels AB, Tuyns AJ. An historical note about the foetal-alcohol syndrome. A letter from Professor Lemoine. Addiction. 1994;89:1021-3. 
10 Lemoine P. The history of alcoholic fetopathies J Popul Ther Clin Pharmacol. 2012;19:e224-6.

11 Roozen S, Peters GJ, Kok G, Townend D, Nijhuis J, Curfs L. Worldwide prevalence of fetal alcohol spectrum disorders: a systematic literature review. Alcohol Clin Exp Res. 2016; 40(1):18.

12 Popova S, Lange S, Poznyak V, Chudley AE, Shield KD, Reynolds JN, et al. Population-based prevalence of fetal alcohol spectrum disorder in Canada. BMC Public Health. 2019;19:845-12.

13 Jones KL, Smith DW. Recognition of the fetal alcohol syndrome in early infancy. Lancet. 1973;302:999-1001.

14 Warner RH, Rosett HL. The effects of drinking on offspring: an historical survey of the American and British literature. J Stud Alcohol. 1974;36:1395-420.

15 Krous HF. Fetal alcohol syndrome: a dilemma of maternal alcoholism. Pathol Annu. 1981; 16(pt.1):295-311.

16 Martin AL. Fetal alcohol syndrome in Europe, 1300-1700: a review of data on alcohol consumption and a hypothesis. Food Foodways. 2003;11:1-26.

17 Calhoun F, Warren K. Fetal alcohol syndrome: historical perspectives. Neurosci Biobehav Rev. 2007;31:168-71.

18 Brown JM, Bland R, Jonsson E, Greenshaw AJ. A brief history of awareness of the link between alcohol and fetal alcohol spectrum disorder. Can J Psychiatry. 2019;64(3):164-8

19 Burton R. The anatomie of melancholy. Part 1, Sect. 2, Memb.1, Subs. 6. 1st ed: Oxford: Henry Cripps; 1638. p. 63.

20 Gellius A. The attic nights. London: J. Johnson; 1795. p. 325.

21 Plutarch M. The symposiacs. In: Goodwin W editor. Plutarch's morals. Boston: Little, Brown \& Co; 1871. p. 217

22 Aristotle. Problemata. In: Forster ES, editor Works of Aristotle: Oxford: Clarendon Press; 1927. p. 871a.

23 Plato . The laws. In: Bury RG, editor. Loeb classical library no. 192. Cambridge MA: Harvard University Press; 1926. p. 775c-d.

24 Temkin O. Soranus' gynecology. Baltimore: The Johns Hopkins Press; 1956. p. 37-9.

25 Roesslin E. The birth of mankind, otherwise called The Womans Book. 1st ed. London: Hood; 1654.

26 Fernel J. Universa Medicina. 1st ed. Paris: Francisci Hackii; 1646. p. 361.

27 Guillemeau J. De la grossesse et accouchement des femmes. Paris: Abraham Pacard; 1620.p. 74

28 Mauriceau F. The diseases of women with child. 1st ed. London: A. Bell; 1716. p. 60.

29 Eminent Physician. The nurse's guide. London: Brotherton and Gilliver; 1729. p. 14.

30 Rodin AE. Infants and gin mania in 18th-century London. JAMA. 1981;245:1237-9.

31 Munk W. The roll of the royal College of physicians. London: The College; 1878. p. 53.

32 Roberts J. The grand-juries of London, Middlesex, and the tower-hamlets: considerations humbly offer'd to the Hon. the house of commons (1725); Appendix to: Wilson T distilled spirituous liquors the bane of the nation. London; 1736. p. 18

33 Clark P. The "mother gin" controversy in the early eighteenth century. Trans R Hist Soc. 1988;38:63-84

34 Hales S. A friendly admonition to the drinkers of Gin, Brandy, and other Distilled Spirituous Liquors. 1st ed. London: B. Dod; 1751. p. 19.

35 Morris C. Observations on the past growth and present state of the City of London; In: A collection of the yearly bills of mortality, from 1657 to 1758. London; 1759.

36 Bouchut E. Hygiène de la première enfance. 7th ed. Paris: JB Baillière; 1879. p. 228.

37 MacNish R. The anatomy of drunkenness. Glasgow: M'Phun; 1828. p. 121

38 Buckingham JS. Report from the select commit tee on inquiry into drunkenness. Evidence on drunkenness, presented to the House of Commons. London: Benjamin Bagster; 1834. p. 284.

39 Howe SG. Report made to the Legislature of Massachusetts, upon idiocy. Boston: Coolidge \& Wiley; 1848. p. 82.

40 Martin H. De l'alcoolisme des parents considéré comme cause d'epilepsie chez leurs descendants. Ann. Med Psychol. 1879;38:48-58.

41 Haddon J. On intemperance in women, with special reference to its effects on the reproductive system. Br Med J. 1876;1(807):748-50.

42 Sullivan WC. A note on the influence of maternal inebriety on the offspring. J Ment Sci. 1899;45(190):489-503.

43 Nicloux M. Sur le passage de l'alcool ingéré de la mere au foetus, en particulier chez la femme. Compt Rend Soc de Biologie. 1899:980-2.

44 Ballantyne JW. Alcoholism and antenatal hygiene. Addiction. 1915;13(2):87-9.

45 Ballantyne JW. Alcohol and antenatal child welfare. Addiction. 1917;14(3):93-116.

46 Gütt A, Rüdin E, Ruttke F. Gesetz zur Verhütung erbkranken Nachwuchses vom 14. Juli 1933. München. J.F. Lehmanns Verlag. 1934;81:127.

47 Fuchs F, Fuchs AR, Poblete VF, Risk A. Effect of alcohol on threatened premature labor. Am J Obstet Gynecol. 1967;99:627-37.

48 Spearing G. Alcohol, indomethacin, and salbutamol: a comparative trial of their use in preterm labor. Obstetrics Gynecol. 1978;53:171-4

49 Desclaux P, Saulairac A, Verdeaux G, Delarue R.Etudeélectroencéphalographique d'enfants arriérés nés de parents alcooliques. Comparaison avec d'autres groupes d'enfants normaux et arriérés. Ann Méd Psychol. 1952;110:40811.

50 Rouquette J. Influence de la toxicomanie alcoolique parentale sur le développement physique et psychique des jeunes enfants. Paris: Thèse; 1957.

51 Lemoine P. Les enfants des parents alcooliques: anomalies observées, a propos de127 cas. Arch Fr Pediatr. 1968:25:830-1.

52 Borteyru JP. La toxicomanie alcoolique parentale et ses répercussions sur la descendance. Nantes: Thèse; 1967.

53 Ulleland C, Wennberg RP, Igo RP, Smith NJ. The offspring of alcoholic mothers. Pediatr Res. 1970;4(5):474.
54 Ulleland CN. The offspring of alcoholic mothers. Ann NY Acad Sci. 1972;197:167-9.

55 Jones KL, Smith DW, Ulleland CN, Streissguth P. Pattern of malformation in offspring of chronic alcoholic mothers. Lancet. 1973;1 1267-71.

56 Majewski F, Bierich JR, Löser H, Costa SD, Eidtmann H, Fasching PA, et al. Zur Klinik und Pathogenese der Alkoholembryopathie (Bericht über 68 Patienten). Münch Med Wochenschr. 1976;118:1635-42.

57 Clarren SK, Smith DW. The fetal alcohol syndrome. Lamp. 1978;35:4-7.

58 Halliday HL, Reid MM, McClure G. Results of heavy drinking in pregnancy. Br J Obstet Gynaecol. 1982;89(11):892-5.

59 Shibley IA, Pennington SN. Historical misrepresentation in science: the case of fetal alcoho syndrome. Sci Eng Ethics. 1998;4:427-35.

60 Combemale F. La descendance des alcooliques. Montpellier: Thèse; 1888

61 Stockard CR. An experimental study of racial degeneration in mammals treated with alcohol. Arch Intern Med. 1912(4):369-98.

62 Pearl R. Some effects of the continued administration of alcohol to the domestic fowl, with special reference to the progeny. Proc Nat Acad Sci USA. 1916;2(12):675-83.

63 Pikkarainen PH, Räihä NC. Development of alcohol dehydrogenase activity in the human liver. Pediatr Res. 1967;1:165-8.

64 Seppälä M, Räihä NC, Tamminen V. Ethanol elimination in a mother and her premature twins. Lancet. 1971;1:1188-9.

65 Clarren SK, Alvord EC, Sumi SM, Streissguth AP, Smith DW. Brain malformations related to prenatal exposure to ethanol. J Pediatr. 1978;92:64-7.

66 Mathews E, Dewees K, Diaz D, Favero C. White matter abnormalities in fetal alcohol spectrum disorders: focus on axon growth and guidance. Exp Biol Med. 2021;246(7):812

67 May PA, Brooke L, Gossage JP, Croxford J, Adnams C, Jones KL, et al. Epidemiology of fetal alcohol syndrome in a South African community in the Western Cape Province. Am J Public Health. 2000;90:1905-12.

68 Robinson GC, Conry JL, Conry RF. Clinical profile and prevalence of fetal alcohol syndrome in an isolated community in British Columbia. CMAJ. 1987;137:203-7.

69 World Health Organization. Global status report on alcohol and health 2018. Geneva: WHO; 2018. p. 41-43.

70 Sedgh G, Singh S, Hussain R. Intended and unintended pregnancies worldwide in 2012 and recent trends. Stud Fam Plann. 2014;45:301-14.

71 Clerk T. The works of William Hogarth. Plate LXIII. Gin Lane. London: R. Scholey; 1812. p 27-30.

72 Bowditch HP. The growth of children. Plate I: height. Boston: Albert J. Wright; 1877.

73 Mac Donald A. Experimental study of children, including anthropometrical and psycho-physical measurements of Washington school children. Washington: US Bureau of Education; 1899 